\title{
Some Atypical Features of Streptococcus sanguis ATCC 10557
}

\author{
JOHN S. COLE III and ROBERT A. KOLSTAD \\ Dental Sciences Department, Naval Medical Research Institute, Bethesda, Maryland 20014, and \\ Department of Microbiology, Medical College of Virginia, Richmond, Virginia 23298 \\ Streptococcus sanguis American Type Culture Collection (ATCC) strain \\ 10557 showed atypical reactions in dextran formation, streptocin activity, and \\ response to mitomycin $\mathrm{C}$ when compared with other $S$. sanguis strains. \\ Therefore, ATCC 10557 must be considered an aberrant member of $S$. sanguis; \\ alternatively, this strain should not be assigned to this species.
}

In 1946, White and Niven (12) isolated a group of $\alpha$-hemolytic streptococci from the blood of endocarditis patients. These isolates, originally called Streptococcus s.b.e., were regarded as belonging to a new species, which White (12) named Streptococcus sanguis. The ability of a microorganism to cause endocarditis does not, however, mean that the microbe is a member of the species $S$. sanguis, since other organisms can cause this disease. Important physiological characteristics of this species included $\alpha$ hemolysis on blood agar, dextran production from $5 \%$ sucrose broth, ammonia production from arginine, fermentation of inulin, and failure to ferment mannitol, sorbitol, or raffinose. However, White and Niven (12) observed certain strains showing atypical reactions in several of these characteristics.

Interest in $S$. sanguis has continued, due to its implication in endocarditis and to its predominance in human dental plaque (3), and the number of isolates of this organism has increased substantially. With this increase, the diversity within $S$. sanguis became more apparent. For example, certain strains can grow on chemically defined media whereas others cannot (4). S. sanguis ATCC 10557 (9) is related serologically to $S$. salivarius HHT (11) and resembles it on mitis-salivarius agar (I. L. Shklair, personal communication). In recent work, we have observed that American Type Culture Collection (ATCC) strain 10557 differs from ATCC 10556, 10558, and other strains of $S$ sanguis in three additional properties.

The bacterial strains studied included $S$. sanguis ATCC 10556, 10557, 10558, S. sanguis F90A, $S$. sanguis enole, $S$. sanguis challis, and other strains of $S$. sanguis as well as $S$. mutans K1R and $S$. mutans GS5. These strains were obtained from the Dental Sciences Department, Naval Medical Research Institute, Bethesda, Md., and from the Center for Disease Control, Atlanta, Ga.

The media used included brain heart infusion broth supplemented with $2 \%$ yeast extract (BHIYE), BHIYE plus $1.5 \%$ agar, sucrose broth (5), and $\mathrm{P}$ broth (8). Difco products were used.

Biochemical activity. Three characteristics of $S$. sanguis which distinguish it from $S$. mutans are: gelling of 5\% sucrose broth and the inability to ferment mannitol or sorbitol (J. D. DeStoppelaar, Ph.D. thesis, Rijksuniversiteit, Utrecht, 1971). ATCC 10557 behaves like neither $S$. sanguis nor $S$. mutans (Table 1).

Antimicrobial inhibition. One interesting characteristic of $S$. sanguis is its ability to inhibit, at least in vitro, the growth of a wide spectrum of streptococci (6). While developing a strain-typing system for $S$. sanguis based on inhibition (E. Crooks, R. Kolstad, and J. Cole, J. Dent. Res., Abstr. 281, 1973), we observed that ATCC 10557 does not share this antimicrobial activity (Table 2).

Insensitivity to mitomycin $\mathbf{C}$. The in vitro inhibition of gram-positive bacteria by $S$. sanguis has been linked to streptocins $(2,7)$. Because bacteriocin induction leads to the death of the activated cell (10), we examined the ability of mitomycin $\mathrm{C}$, an effective inducing agent of some bacteriocins (1), to kill cultures of ATCC 10557. This strain, when 
TABLE 1. Differential characteristics of Streptococcus sanguis and S. mutans ${ }^{a}$

\begin{tabular}{l|c|c|c}
\hline \multicolumn{1}{c|}{ Strain } & $\begin{array}{c}\text { Gelling of } \\
5 \% \text { sucrose }\end{array}$ & $\begin{array}{c}\text { Mannitol } \\
\text { fermentation }\end{array}$ & $\begin{array}{c}\text { Sorbitol } \\
\text { fermentation }\end{array}$ \\
\hline Streptococcus sanguis ATCC 10556 & ++++ & - & - \\
Streptococcus sanguis ATCC 10557 & - & - & - \\
Streptococcus sanguis ATCC 10558 & +++ & - & - \\
Streptococcus sanguis F90A & ++++ & + & + \\
Streptococcus mutans K1 R & - & + & + \\
Streptococcus mutans GS5 & - & + & + \\
\hline
\end{tabular}

${ }^{a}$ Methodology according to J. D. DeStoppelaar, Ph.D. thesis, Rijksuniversiteit, Utrecht, 1971.

TABLE 2. Streptocin production by various strains of Streptococcus sanguis. ${ }^{a}$

\begin{tabular}{|c|c|c|c|c|c|c|c|c|c|c|}
\hline \multirow[b]{2}{*}{$\begin{array}{l}\text { Sensitive } \\
\text { indicators }\end{array}$} & \multicolumn{10}{|c|}{ Streptocin-producing strains ${ }^{b}$} \\
\hline & $\begin{array}{l}\text { ATCC } \\
10556\end{array}$ & $\begin{array}{l}\text { ATCC } \\
10557\end{array}$ & $\begin{array}{l}\text { ATCCS } \\
10558\end{array}$ & Challis & F90A & Enole & 410 & $174 \mathrm{P}$ & 167 & Wicky \\
\hline Streptococcus salivarius 1 & + & - & + & + & + & + & + & + & + & + \\
\hline Streptococcus salivarius 3 & + & - & + & + & + & + & + & + & + & + \\
\hline Streptococuus bovis ATCC 9809 & + & - & + & + & + & + & + & + & + & + \\
\hline Streptococcus mutans GS5 & + & - & + & + & - & + & + & + & + & + \\
\hline Streptococcus mutans SL1 & + & - & + & + & + & + & + & + & + & + \\
\hline Streptococcus mutans $\mathrm{BHT}^{2}$ & + & - & + & + & + & + & + & + & + & + \\
\hline Streptococcus mutans $\mathrm{C} 4$ & + & - & + & + & + & + & + & + & + & + \\
\hline
\end{tabular}

${ }^{a}$ Methodology of reference 6 .

${ }^{b}$ Symbols: + , clear ring around producer spot; - , no ring around producer spot.

TABLE 3. Effect of mitomycin $C$ on strains of Streptococcus sanguis ${ }^{a}$

\begin{tabular}{c|c|c}
\hline Strain & - Mitomycin C & + Mitomycin C \\
\hline ATCC 10556 & $65^{b}$ & 35 \\
ATCC 10557 & 123 & 101 \\
ATCC 10558 & 56 & 20 \\
174P & 105 & 48 \\
Challis & 118 & 52 \\
167 & 111 & 26 \\
\hline
\end{tabular}

${ }^{a}$ Methodology according to reference 8 .

$b$ Klett values, green filter, $2 \mathrm{~h}$ after treatment; zero-time Klett readings were 23 to 25 .

exposed to $0.1 \mu \mathrm{g}$ of mitomycin $\mathrm{C}$ in $\mathrm{P}$ broth (10) for $2 \mathrm{~h}$, is relatively insensitive to the drug, whereas five representative strains of $S$. sanguis are sensitive (Table 3 ).

In conclusion, ATCC 10557, originally assigned to the species $S$. sanguis by White and Niven (12) because it was isolated from the blood of an endocarditis patient, differs in several properties from representative members of the species. ATCC 10557 must be considered an aberrant member of $S$. sanguis; alternatively, this strain should not be assigned to this species.

\section{ACKNOWLEDGMENTS}

This project was supported in part by work unit MF 12.524.012.0017AG31 and in part by contract 325 from the International Sugar Research Foundation to R.K.

\section{REPRINT REQUESTS}

Address reprint requests to: Dr. John S. Cole III, Dental Sciences Department, Naval Medical Research Institute, Bethesda, Md. 20014.

\section{LITERATURE CITED}

1. Brandis, H., and J. Smarda. 1971. Bacteriocine und bacteriocinähnliche Substanzen. VEB Gustav Fisher Verlag, Jena.

2. Brock, T. D., and J. M. Davie. 1963. Probable identity of a group D hemolysin with a bacteriocine. J. Bacteriol. 86:708-712.

3. Carlsson, J. 1968. A numerical taxonomic study of human oral streptococci. Odontol. Rev. 19: 137-160.

4. Carlsson, J 1970. Chemically defined medium for growth of Streptococcus sanguis. Caries Res. 4:297-304. 
5. De Moor, C. E. 1962. Streptokokkenonderzoek in 1960. Versl. Meded. Volksgezondh. 1962:129.

6. Holmberg, K., and H. O. Hollander. 1972. Interference between gram-positive microorganisms in dental plaque. J. Dent. Res. 51:588-595.

7. Kelstrup, J., and R. J. Gibbons. 1969. Bacteriocins from human and rodent streptococci. Arch. Oral Biol. 14:251-258.

8. Parsons. C. L., A. G. Colon, C. G. Leonard, and R. M. Cole. 1972. Isolation of bacteriophages from group H streptococci. J. Virol. 9:876-878.

9. Porterfield, J. S. 1950. Classification of the streptococci of subacute bacterial endocarditis. J. Gen. Microbiol. 4:92-101.

10. Reeves, P, 1972. The bacteriocins. SpringerVerlag, New York.

11. Tow, H. D. and I. L. Shklair. 1967. The serological relationships of certain cariogenic and potentially cariogenic streptococci. Naval Dental Research Institute, PR 67-06, Great Lakes, Ill.

12. White, J. C., and C. F. Niven. 1946. Streptocccus s.b.e.: a streptococcus associated with subacute bacterial endocarditis. J. Bacteriol. 51:717-722. 